\title{
FIQH OF DIFFABLE IN THEO-ANTRO-JURIDICAL PERSPECTIVE: EXAMINING THE DIVINE, HUMANE AND CONSTITUTIONAL FOUNDATION FOR THE FULFILLMENT OF THE RIGHTS OF DISABLED GROUP
}

\author{
Siti Rohmah \\ Lecturer at Faculty of Law, Brawijaya University \\ Email: sitirohmah@ub.ac.id \\ Moh. Anas Kholish \\ Lecturer at Syariah Faculty, UIN Maulana Malik Ibrahim / Researcher at Pojok Peradaban Institute \\ Email: kholishmuhamad85@gmail.com \\ Andi Muhammad Galib \\ Researcher at Pojok Peradaban Institute \\ Email: andimuhammadgalib11@gmail.com
}

\begin{abstract}
Since the past, stigma and various forms of discrimination have continued to haunt disabled groups. They become a group that is marginalized from society due to the limitations they experience. Diffable groups should be seen as part of a society that has different abilities. In Islamic doctrine, marginalization and discrimination against these disabled groups is an act that is blamed and prohibited because basically all humans have the same position before God and the only difference is the degree of holiness. Therefore, Islamic law through fiqh products must participate in legitimizing the fulfillment of rights for disabled groups from a religious perspective. This paper will examine the importance of the formulation of fiqh with disabilities as part of respecting human values taught by Islam. Using the theo-anthro-juridical term, this paper will also describe the foundations in formulating the figh of persons with disabilities, including theological, humanist, and legal foundations.
\end{abstract}

Keywords: Fiqh of Diffable, Theo-Anthro-Juridical, Disabled Group

\begin{abstract}
Abstrak
Sejak dulu stigma dan berbagai bentuk diskriminasi terus menghantui kelompok difabel. Mereka menjadi kelompok yang terpinggirkan dari masyarakat disebabkan keterbatasan yang mereka alami. Padahal, kelompok difabel sejatinya harus dilihat sebagai bagian dari masyarakat yang memiliki kemampuan yang berbeda. Dalam doktrin Islam, peminggiran dan diskriminasi terhadap kelompok difabel ini merupakan perbuatan yang dicela dan dilarang, karena pada dasarnya semua manusia memiliki kedudukan yang sama di hadapan Tuhan dan yang membedakan hanyalah derajat ketakwaannya. Oleh karenanya, hukum Islam melalui produk fikih harus ikut
\end{abstract}

Nur El-Islam, Volume 8, Nomor 1, April 2021 
melegitimasi pemenuhan hak bagi kelompok difabel dalam perspektif agama. Tulisan ini akan mengkaji mengenai pentingnya formulasi fikih difabel sebagai bagian dari penghormatan nilai-nilai kemanusiaan yang diajarkan Islam. Dengan menggunakan istilah teo-antro-yuridis, tulisan ini juga akan memaparkan landasan-landasan dalam merumuskan fikih difabel yang meliputi landasan teologis, humanis dan hukum.

Kata kunci: Fikih Difabel, Teo-Antro-Yuridis, Kelompok Difabel.

\section{A. Introduction}

Humans are creatures of God who were created with the perfect form, among other creatures. In the doctrine of Islamic theology, humans are the best of creation (fi ahsani taqwiim) equipped with an extraordinary gift, namely reason to distinguish between good and evil (fa alhamaha fujuraha wa taqwaha). ${ }^{1}$ This is what underlies the concept of equality between humans in Islam. Islam clearly states that every human being has the same degree; the only difference between them is their level of piety before God. Therefore, discriminatory behavior in any form is hated and categorized as a disgraceful act in Islamic teachings. The presence of Islam aims to liberate humans from various forms of oppression, discrimination, and exploitation in various aspects of life. Islam expressly opposes injustice and neglect of human rights and principles. ${ }^{2}$

The creation of man as a perfect creature and the best of creation at this point must be understood not in the context of mere physical perfection. Some humans are born with physical, mental, and intellectual limitations. This group today is referred to as a group of people with disabilities or persons with disabilities. However, these limited conditions do not necessarily make them a marginalized group and receive discriminatory treatment. In historical records, this disabled group has indeed experienced various unpleasant treatments and is far from human values.

If we want to look back, discrimination against people with disabilities has existed since the time of ancient human civilization.

\footnotetext{
h. 125-126.

${ }^{2}$ M Syukri Ismail, “Prinsip Kemanusiaan Dalam Islam” 5 (2018): 24. h. 187.
}

${ }^{1}$ Wahbah az-Zuhalili, Tafsir Al-Munir (Damaskus: Dar al-Fikr al-Muashir, 1418). 
For example, in Greek civilization, people with disabilities received pejorative nicknames such as "moros," which means stupid or retarded. The disabling conditions they experienced were seen by society at that time as God's punishment to humans, one of which was caused by sins or violations that humans committed. The same thing can also be found in the history of the civilization of the Jewish community or the Chinese nation in the past, which saw this group other than as a form of God's punishment, as well as people who were sick, so they had to undergo treatment in such a way or even in certain contexts had to be separated from society. ${ }^{3}$

The societal stigma that considers people with disabilities as "sick" has continued into modern times. This can be seen, for example, from the policy issued by the Dutch colonial government, which specifically built hospitals that functioned to accommodate people who have these limitations. In fact, in an even more heartbreaking context, during the reign of the Nazis in Germany, these people with disabilities received cruel treatment such as violence to massacres (genocide) known as the Holocaust that occurred throughout the 1940 s. ${ }^{4}$ Of course, these historical traces must be a lesson for today's human civilization, which should respect human values more, including attention to the fulfillment of human rights for disabled groups.

As a religion that carries a mission of salvation for the universe, Islam pays great attention to the fulfillment of rights for disabled groups. In addition, religious narratives that specifically pay attention to people with disabilities can also be found in the treasures of Islamic teachings. In the context of fiqh, the concept of rukhsoh in the implementation of worship gives us an idea of how Islam is very friendly to disabled groups. In the concept of rukhsoh related to the implementation of mahdoh worship such as prayer, for example, Islam determines that if a person is unable to carry out his obligations by

\footnotetext{
${ }^{3}$ Rifai Shodiq Fathoni, “Menelusuri Sejarah Difabel Pada Masa Kuno,” Wawasan Sejarah (blog), June 10, 2020, https://wawasansejarah.com/sejarah-difabel-masa-kuno/.

${ }^{4}$ Donald L. Niewyk and Francis R. Nicosia, The Columbia Guide to the Holocaust (Columbia University Press, 2003). h. 45-52.
} 
standing properly, he gets relief from praying sitting down. And if sitting is still not possible, then it is permissible to lie down facing the Qiblah. This follows the fiqh rules, which state "al-masyaqqah tajlib al-taysir" which can be interpreted as every difficulty can bring ease. ${ }^{5}$

Narratives like the one above are important to be brought up in seeing the various complex problems of disabled groups today. The formulation of the concept of fiqh, which specifically discusses diffability, is deemed necessary to provide theological legitimacy for the fulfillment of rights and equal treatment for people with disabilities in various fields of life. This paper will explain the importance of fiqh formulations for people with disabilities whose level is felt to occupy the same position as other existing fiqh products, such as minority figh, human rights fiqh, environmental fiqh, and so on. This paper will also attempt to examine the foundations built on the theological, humanitarian and legal aspects of the formulation of the fiqh of diffability. The theological aspect will talk about relevant religious doctrines. The humanitarian aspect will talk about the principles of human rights and universal humanism values. In contrast, the legal aspect will specifically look at how the legal arrangements in legislation related to disabled groups are either based on international conventions and laws and regulations in Indonesia.

\section{B. Understanding Disability and Diffability}

Etymologically, "disability" is defined as "A physical or mental condition that limits a person's movements, senses, or activities." 6 Meanwhile, in the Cambridge Dictionary, "disability" is defined in the following context as "an illness, injury, or condition that makes it difficult for someone to do the things that other people do." some things like other people do." From these two definitions alone, there is a significant difference in interpreting what disability is. The two

${ }^{5}$ Muhammad Shidqi bin Ahmad Al-Burnu, Mausuah Al-Qawaid Al-Fiqhiyah, 9th ed. (Beirut: Muassisah al-Risalah, 2003). h. 632.

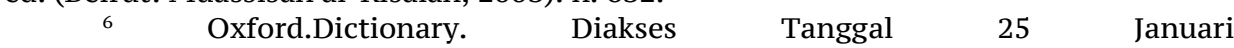
2021.<https://Www.Oxfordlearnersdictionaries.Com/>,” n.d. 
differences can be seen from the meaning that sees disability as a mere physical limitation and physical limitations, which are understood as illness or injury, or also commonly known as people with disabilities.

The term for naming diffability groups as "people with disabilities" does have a long history. In the context of Indonesia, the use of this term is even applied in various official documents or products of state law. ${ }^{7}$ In the rule of law, there are several labels for people with disabilities, both in-laws, government regulations, and regional regulations. For example, the term disability in Law Number 6 of 1974 concerning Basic Provisions for Social Welfare is understood as a disturbed person or has lost his ability to protect his life. ${ }^{8}$

Such labeling, of course, leads to the potential for discrimination. Or even tend to lead to hate speech actions caused by a misconception in the community. It is as if there is a dividing wall between people with disabilities and normal people. As a result, understanding, and labeling like this can trigger a very simplistic meaning from society, which encourages marginalization and discriminatory actions in various aspects of life. ${ }^{9}$ In this context, according to Hogan, the use of the term "disabled," which refers more to a medical condition, has implications for its treatment which is carried out through medical treatment. ${ }^{10}$

What is meant by diffability is the condition of a person who is considered to have different abilities. The term "diffable" itself is an abbreviation of the words "different" and "abbled." This term emphasizes that even with their limitations, people with disabilities can still do things in other ways. Moving the feet, for example, is a way

\footnotetext{
${ }^{7}$ Arif Maftuhin, "Mengikat Makna Diskriminasi: Penyandang Cacat, Difabel, Dan Penyandang Disabilitas,” INKLUSI 3, no. 2 (August 8, 2016), https://doi.org/10.14421/ijds.030201. h. 146-147.

${ }^{8}$ Maftuhin. H. 143-144.

${ }^{9}$ Peter L Berger and Thomas Luckmann, "The Social Construction of Reality," n.d., 125. h. 43-35.

${ }^{10}$ A. Llewellyn and K. Hogan, "The Use and Abuse of Models of Disability," Disability \& Society 15, no. 1 (January 2000): 157-65, https://doi.org/10.1080/09687590025829. h. 158-160.
} 
to mobilize ourselves from one particular place to another. Therefore, people with physical disabilities can perform other forms of movement with the help of a wheelchair to move from one place to another differently from ordinary people. ${ }^{11}$

The term diffability was first proposed around the 1980s as an alternative to the term "disability" or people with disabilities. This is done because it can give a more positive message and avoid discrimination against groups with these limitations. ${ }^{12}$ In this context, the proper term to describe or classify groups with physical and mental limitations is diffability, translated with different skills or abilities.

\section{The Urgency of Fiqh with Disabilites}

As previously stated, the discrimination and stigma experienced by people with disabilities have existed for a long time. In the past, this group of people with disabilities has become a marginalized group of people and seems to be separated from society due to the differences or "lack". Pejorative terms that tend to regard people with disabilities as stupid and backward in the past are examples of longstanding forms of discrimination. In the belief of the Jewish community in the past, the condition of disability was considered a form of punishment from Yahweh (God of the Jews) for violations committed by humans. Whereas in the civilization of Chinese society in the past, people with disabilities were considered sick people, so they needed to undergo treatment, and so on. ${ }^{13}$

In Europe, people with disabilities are eliminated from society. In the history of Nazi Germany, for example, people with disabilities have experienced callous treatment. They were arrested and put in prison until they were killed using poison gas during the Holocaust throughout the 1940s. Nazi Germany, under the leadership of Adolf Hitler at that time, considered that the Aryan race (the German race)

\footnotetext{
${ }^{11}$ Maftuhin, “Mengikat Makna Diskriminasi.” h. 149

12 Oxford.Dictionary. Diakses Tanggal 25 Januari 2021.<https://Www.Oxfordlearnersdictionaries.Com/>."

${ }^{13}$ Fathoni, "Menelusuri Sejarah Difabel Pada Masa Kuno."
} 
was the best and had the highest position of all human races on earth, so they needed to clean up other races that were considered imperfect. Massacres and massacres (genocide) are committed against those who are considered imperfect, such as people with disabilities. ${ }^{14}$

Circumstances that make people with disabilities into an isolated and marginalized group like this occur in many places. In Australia, before the 1980s, people with disabilities were placed in exceptional hospitals for people with disabilities. The same condition also happened in Indonesia during the Dutch colonial occupation. At that time, the colonial government built many hospitals for people with disabilities and implemented a system of shackles for them. The colonial government also created issues and opinions that people with disabilities were a curse and a symbol of hereditary sin and became a burden. This was based on the colonial government's reasoning that people with disabilities could not be used in the Dutch East Indies military. ${ }^{15}$

This background and social conditions have led to various theories and advocacy movements for persons with disabilities. Normalization Theory (Normalization Theory), initiated by Wolf Wolfsenberger in 1970, is one of them. This theory states that people with disabilities have the same rights as citizens. There should be no discrimination and elimination of persons with disabilities, and the state must fulfil their rights. In Wolfsenberger's view, the act of "imprisoning" persons with disabilities is considered inhumane and violates human rights principles. This theory then became the rationale for abolishing institutions that were considered to imprison persons with disabilities and the development of the concept of family care or community living as part of the implementation of human rights principles.

\footnotetext{
${ }^{14}$ Niewyk and Nicosia, The Columbia Guide to the Holocaust. h. 45-52.

${ }^{15}$ Nurul Saadah Andriani, “Kebijakan Responsif Disabilitas: Pengarusutamaan Managemen Kebijakan di Level Daerah, Nasional dan Internasional,” PALASTREN Jurnal Studi Gender 9, no. 1 (February 26, 2017): 189-214, https://doi.org/10.21043/palastren.v9i1.2056. h. 202.
} 
In 1983, Wolfsenberger developed his normalization theory by coining the theory of Social Role Volarization (social role theory). This theory is general, not only discussing persons with disabilities but also other marginalized communities. This theory states that people with disabilities also have a social role in society. This is because many rejections in society think that a person with a disability does not have a social role. They even tend to attach a negative stigma or labelling to the existence of this group. ${ }^{16}$

This awareness of the importance of respect for human rights and equality for disabled groups has led to advocacy movements at the international and national levels. At the international level, this is evidenced by the development of narratives that support the equality of disabled groups and international rules drawn up by international institutions such as the United Nations. At the national level, many countries in the world are currently ratifying the convention on disabled groups. At this point, Islamic law, which is manifested by fiqh products, should also make this disability issue a critical issue and must be formulated in such a way. This is done so that Islamic teachings can always respond to various conditions and situations of society, especially those related to humanity which receive special attention in Islamic teachings.

\section{Fiqh of Diffable in Theological Perspective}

Islam is very concerned about the rights of people with disabilities, especially in social life. This can be proven by the existence of a particular study related to the alignments of Allah SWT., which provides special rights for persons with disabilities so as not to be discriminated against in society. Even in fiqh studies, people with disabilities are given a dispensation in religious practice. One of the simplest examples is in terms of prayer. In Islam, a person who cannot pray standing up is allowed to perform it sitting down. And if sitting is

\footnotetext{
${ }^{16}$ Wolf Wolfensberger, “A Brief Overview of Social Role Valorization,” Ment Retard 38, no. 2 (2000), https://doi.org/10.1352/00476765(2000)038<0105:ABOOSR>2.0.CO;2. h. 105-123.
} 
not possible, then it is permissible to lie down facing the Qiblah, and so on. ${ }^{17}$

Islam has laid down universal humanist principles for people with disabilities. All ubudiyah practices in Islam are very inclusive and friendly to people with disabilities. Although worship in a usual way is the ideal standard, if there is a physical deficiency in a servant, then the ubudiyah standard can be lowered according to the abilities of the disabled. This narrative is called "fiqh of diffable". The universal principles that become the theological standing for the realization of inclusive education in an Islamic perspective include: First, Adam alHaraj (not making it difficult). In its implementation of establishing Islamic shari'ah, the Qur'an always takes into account human capabilities in carrying it out, and this can be seen in the opportunities and concessions to humans so that they can accept legal provisions with the abilities of the people. In this context, Islam has never imposed its ubudiyah standards on those who are considered disabled. Islamic law always provides concessions for people with disabilities. Al-Syatibi in al-Muwafaqat states that human ability is an absolute requirement in accepting legal provisions.

Second, Taqlil al-taklif (facilitate and lighten the burden). This principle in Islamic Shari'ah aims to realize the benefit of the people, while the wisdom of a legal provision is always oriented towards convenience. As for changes, changes, and even the abolition of the law, it is evidence that Islamic law has always been oriented towards the convenience and benefit of humankind, especially for people with disabilities who have limited abilities. Third, in line with the universal benefit. Humans as the subject of the legal legislation of the Qur'an, then all Islamic law in the Qur'an is intended for the benefit and improvement of the people both in terms of religion, soul, reason, honour, descent, property and environment. Moreover, the fourth is musawa and 'adalah. Equality and justice are absolute requirements in

${ }^{17}$ Mohammad Yazid Mubarok, "Hak-Hak Dan Kewajiban Kaum Disabilitas Sebelum Dan Setelah Islam Datang | Islamic Academika,” accessed July 9, 2021, http://ejurnal.staiattaqwa.ac.id/index.php/ojs/article/view/84. 
the law, both in matters of muamalah and worship. The equality of rights implies justice. Equality and justice are two things that are inseparable in establishing a law for the maintenance of human life.

In addition to the universality principles of Islamic sharia above, the portrait of inclusive education for the disabled is also fascinating if it is based on the historical background of the revelation of the verse in Surah A'basa verses 1 to 10 regarding justice for giving equal attention to persons with disabilities and ordinary people in general. Word of Allah SWT. reads:

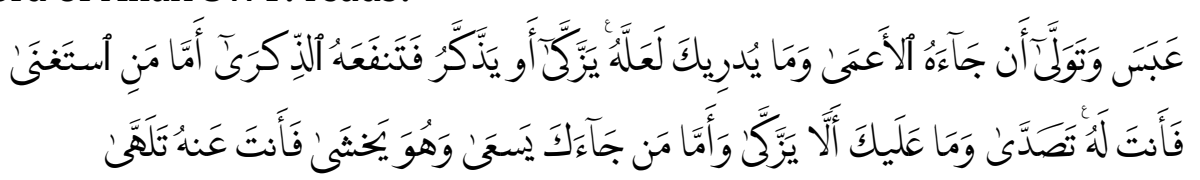

"He (Muhammad) frowned and turned away, for a blind man had come to him. Do you know maybe he wants to cleanse himself (from sin), Or he (want to) get teaching, then the teaching benefits him? As for the person who thinks he is self-sufficient, then you serve him. However, there is no (reproach) on you if he does not cleanse himself (belief). Furthermore, as for those who come to you in haste (to get instruction). While he is afraid of (Allah). Then you ignore it"

The scholars' commentaries explained that the revelation of this verse was due to the attitude of the Prophet Muhammad towards a blind friend named Abdullah bin Ummi Maktum. The story relates to the arrival of Abdullah bin Ummi Maktum in a meeting of the Meccan political elite, which was attended by the Prophet Muhammad, intending to preach so that the infidels of Quraish could embrace Islam. However, the arrival of Abdullah bin Ummi Maktum interrupted the Prophet's conversation with the political elite of Mecca, so that Prophet Muhammad turned sour and turned his face away from Abdullah bin Ummi Maktum Allah SWT considered the attitude of the Prophet Muhammad as an attitude that is not commendable to humans, especially friends with disabilities. Then, Allah SWT rebukes the Prophet Muhammad. by sending His word to him. This proves that people with disabilities get protection and defence from Allah SWT. 
even from the attitude and actions of the Prophet Muhammad, who at that time seemed to ignore him. ${ }^{18}$

In this regard, the Qur'an has a unique point of view in viewing disability. The essence of the mention of persons with disabilities discussed in the Koran contains the meaning of a social model. Based on the verses that talk about a dispensation for people who cannot carry out religious orders, Islam views disability as something that is natural and may happen because many possibilities can make someone a person with a disability, such as accidents, disasters, or various events that cause a person to experience reduced organ function and so on. Such things should not make persons with disabilities a marginal group in society. This confirms that persons with disabilities are not a minority group. They are human beings who have the same rights and positions as humans in general. ${ }^{19}$

The Qur'an has several editorials that connote disability, but in its use, it tends to have a metaphorical meaning, not an essential meaning. Thus, the meaning of the terms for persons with disabilities referred to in the Qur'an is not in the context of physical disabilities. This fact has a tremendous impact on the meaning of the terms that revolve around the term disability in the Qur'an. Some forms of disability that exist in the Qur'an are a'ma, abkam, asham, a'raj, and shufaha'. ${ }^{20}$

The word al-a'ma (blind), for example, does not only lead to a physical meaning that tends to be negative. Muttaqin explained that the meaning of the word al-a'ma, which refers to people with visual impairments, with various versions of its derivation in 33 verses of the Qur'an, displays more of a metaphorical meaning than the actual meaning. The meaning is for social criticism to the community who

\footnotetext{
${ }^{18}$ Jalauddin as-Suyuthi, Asbabun Nuzul: Sebab Turunnya Ayat al-Quran (Jakarta, Indonesia: Gema Insani, 2008).

${ }^{19}$ Khairunnas Jamal, Nasrul Fatah, and Wilaela Wilaela, “Eksistensi Kaum Difabel Dalam Perspektif Al-Qur'an,” Jurnal Ushuluddin 25, no. 2 (December 14, 2017): 221, https://doi.org/10.24014/jush.v25i2.3916.

${ }^{20}$ Quraish Shihab, Tafsir Al-Mishbah, Pesan, Kesan Dan Keserasian al-Qur'an, Jilid 8 (Ciputat: Lentera Hati, 2009).
} 
considers them to be a despised group because of their physical disability. Therefore, the Qur'an emphasizes that the true essence of meaning is the blindness of the inner eye, where the condition of the blindness of the inner eye is considered worse in the sight of God than physical blindness.

In this context, the Qur'an presents the opposite of the word a'ma, not bashoro but bashiro. As stated in his word, "la yastawi ala'ma wal bashir". Bashor is defined as physically blind, but bashir is interpreted as heart blind. Likewise, the use of meaning can also be used for the word abkam and its derivation six times with various contexts, asham and a'raj and their derivation 15 times and ten times, respectively, and the word shufaha' and its derivation which are mentioned 11 times in the Qur'an. ${ }^{21}$

\section{E. Fiqh of Diffable in Human Rights and Legal Perspective}

From a universal humanitarian point of view, the birth of the Convention on the Rights of Persons with Disabilities (CRPD) at the United Nations (UN) is one of the efforts made to fulfil and protect the human rights of persons with disabilities. Before this convention, several instruments from the United Nations regarding the human rights of persons with disabilities. In the 1970s, two declarations were promulgated, namely the Declaration on Persons with Mental Disabilities (1971) and the Declaration on the Rights of Persons with Disabilities (1975). However, these early instruments still reflect the idea of disability as a medical model. The model views people with disabilities as people with medical problems whose treatment depends on each country's social security and welfare.

Then in 1993, the United Nations adopted the Standard Rules on the Equalization of Opportunities for Persons with Disabilities (STRE). This STRE emphasizes equality for people with disabilities, namely the principle that implies equal rights and states that the needs of each individual are equally important, and these needs must be used as the

${ }^{21}$ Mubarok, "Hak-Hak Dan Kewajiban Kaum Disabilitas Sebelum Dan Setelah Islam Datang | Islamic Academika.” h. 122-131. 
basis for community planning by the state. This instrument emphasizes that all resources should be used in such a way as to ensure that every individual has an equal opportunity to participate in society. ${ }^{22}$

In the conception of universal human rights, several fundamental principles form the basis of various human rights instruments issued by the United Nations and ratified by many countries globally, namely: a. Equality Principle; b. the Principle of Non-Discrimination; c. The principle of the State's obligation to protect the rights of its citizens; d. Non-Derogable Principles (human rights are inherent in every human being); and e. Indivisible principle (fundamental rights are rights that cannot be separated and interrelated). What is very fundamental in human rights is the idea that all people are born free and have equality. This principle emphasizes that humans are equal in terms of their dignity and worth. The differences inherent in humans do not cause human positions to become unequal because even so, they are still human beings created by God in the best possible way. ${ }^{23}$

In this context, the concept of inclusiveness in seeing different groups, including groups with disabilities, becomes essential. Openness, equality and respect for differences as fair diversity are important aspects and are essential in the conception of inclusiveness. The aspect of openness means that everyone who lives is and is active in a community, whether in the family, school or society at large, must feel safe and comfortable, get their rights, and carry out their obligations properly. The aspect of equality means positioning human entities as individuals who have different personal barriers, which can be due to age, knowledge, distance, economic conditions, and communication, in an equal and proportional position. Respect for differences means that diversity, whether culture, language, gender, race, ethnicity, economy, and differences in physical and mental

${ }^{22}$ Fajri Nursyamsi, Kerangka Hukum Disabilitas Di Indonesia: Menuju Indonesia Ramah Disabilitas, Cetakan pertama (Jakarta: Pusat Studi Hukum dan Kebijakan, 2015). h. 15-16.

${ }^{23}$ Nursyamsi. h. $17-20$ 
abilities, must be understood as a natural diversity and must be accepted. So this will create beautiful conditions and mutual respect in the community.

Difability conditions are not only caused by congenital abnormalities or from the womb, but disability can also occur in everyone, both children, adolescents, adults, to the elderly. ${ }^{24}$ Various things can be the cause of disability, such as traffic accidents, victims of crime, work accidents or natural disasters, so that everyone has the potential to be disabled. Therefore, these disabled groups need to get legal protection from the state to guarantee and fulfil their rights as citizens like other citizens.

In the context of Indonesia, the state constitution has firmly guaranteed the protection and fulfilment of the human rights of persons with disabilities. The 1945 Constitution of the Republic of Indonesia, as the grand norm or basis of various laws and regulations in Indonesia, states in Article $28 \mathrm{H}$ paragraph (2) that "everyone has the right to receive special facilities and treatment to obtain the same opportunities and benefits in order to achieve equality and justice. " At first glance, this article seems to apply very generally because it uses the term "everyone", which means that the provision is intended for every Indonesian citizen. However, the Constitutional Court in several decisions has given interpretations regarding this provision, namely in the Constitutional Court Decision Number 10-17-23/PUU-VII/2009, the Constitutional Court Decision Number 143/PUU-VII/2009 and the Constitutional Court Decision Number 16/ PUU-VIII/2010.

In the three decisions mentioned above, the Constitutional Court explained that "constitutional rights in article $28 \mathrm{H}$ paragraph (2) of the 1945 Constitution of the Republic of Indonesia are constitutional guarantees for those who experience marginalization, backwardness, exclusion, restrictions, distinctions, gaps in participation in politics and public life that originate from structural and socio-cultural inequality of society continuously (discrimination),

${ }^{24}$ M. Syahbuddin Latief, Jalan Kemanusiaan, Panduan Untuk Memperkuat Hak Asasi Manusia (Yogyakarta: Lapera Pustaka Utama, 1999). h. 40. 
both formal and informal, in public and private spheres or known as affirmative action. ${ }^{25}$

This interpretation of the Constitutional Court clearly emphasizes that the state is obliged to protect every citizen, including groups of people with disabilities who have often been subjected to various discriminatory actions and neglect. This interpretation also confirms that the disabled have the right to get special facilities and treatment (affirmative action) because of the conditions they experience to fulfil their constitutional rights as citizens. ${ }^{26}$ This provision must then become the basis for the formation of various laws and regulations that are friendly to people with disabilities because people with disabilities are also part of the country's citizens.

Law Number 39 of 1999 concerning Human Rights, as the spearhead of legal regulations protecting the rights of citizens, further emphasizes the need to fulfil the various fundamental rights of these disabled groups. Article 12 of the Human Rights Law states that "everyone has the right to protection for his personal development, to obtain education, to educate himself, and to improve the quality of his life in order to become a human being who is faithful, devoted, responsible, noble, happy, and prosperous in accordance with human rights." ${ }^{27}$ Coupled with the ratification of the Convention on the Rights of Persons with Disabilities (CRPD) through Law No. 19 of 2011 by the government, making the fulfilment of rights for people with disabilities a critical element in policymaking and further affirming the responsibility of the state through institutions against them.

In particular, Law Number 19 of 2011 concerning the Ratification of the International Convention on the Rights of Persons with Disabilities emphasizes the promotion, respect, fulfilment and protection of the rights of persons with disabilities by the state. Article 9 of this Law affirms that in order for persons with disabilities to be able to live independently and participate fully in all aspects of life,

\footnotetext{
25 "Putusan Mahkamah Konstitusi Nomor 10-17-23/PUU-VII/2009” (n.d.).

${ }^{26}$ Nursyamsi, Kerangka Hukum Disabilitas Di Indonesia. h. 23.

27 “Undang-Undang Nomor 39 Tahun 1999 Tentang Hak Asasi Manusia” (n.d.).
} 
countries that ratify the International Convention on the Rights of Persons with Disabilities must adopt appropriate policies to ensure access for persons with disabilities, on an equal basis with others.

\section{F. Conclusion}

The issue of disability is an issue that is of concern to the world today. Equality and fulfilment of rights for groups that have been mistreated, discriminatory and marginalized have triggered advocacy movements from various elements. At this point, fiqh, as a product of Islamic law, also needs to participate in legitimizing the need for equality and fulfilment of the rights of disabled groups through fiqh with disabilities. Islamic law must always show relevance and solutions in seeing the reality that occurs in this context of the disabled group. This is where the actuality of Islamic law lies and remains an instrument for achieving benefit.

In this context, fiqh for disabled groups is very important to be unstuck to be formulated. The formulation of fiqh for persons with disabilities is based on three aspects: theological, humanitarian, and applicable legal rules. The theological foundation refers to the spirit of justice and equality in Islamic teachings based on the Qur'an and the Sunnah of the Prophet. The humanitarian foundation refers to universal humanitarian doctrines and principles that are configured in various international conventions. At the same time, the legal basis refers to various state legal rules that guarantee the fulfilment of the rights of its citizens, especially groups of people with disabilities.

\section{Bibliography}

Al-Burnu, Muhammad Shidqi bin Ahmad. Mausuah Al-Qawaid AlFiqhiyah. 9th ed. Beirut: Muassisah al-Risalah, 2003.

Andriani, Nurul Saadah. "Kebijakan Responsif Disabilitas: Pengarusutamaan Managemen Kebijakan di Level Daerah, Nasional dan Internasional.” PALASTREN Jurnal Studi Gender 9, 
no. 1 (February 26, 2017): 189-214. https://doi.org/10.21043/palastren.v9i1.2056.

Berger, Peter L, and Thomas Luckmann. "The Social Construction of Reality,” n.d., 125.

Fathoni, Rifai Shodiq. "Menelusuri Sejarah Difabel Pada Masa Kuno.” Wawasan Sejarah (blog), June 15, 2020. https://wawasansejarah.com/sejarah-difabel-masa-kuno/.

Ismail, M Syukri. “Prinsip Kemanusiaan Dalam Islam” 5 (2018): 24.

Jalauddin as-Suyuthi. Asbabun Nuzul: Sebab Turunnya Ayat al-Quran. Jakarta, Indonesia: Gema Insani, 2008.

Jamal, Khairunnas, Nasrul Fatah, and Wilaela Wilaela. "Eksistensi Kaum Difabel Dalam Perspektif Al-Qur'an.” Jurnal Ushuluddin 25, no. 2 (December 14, 2017): 221. https://doi.org/10.24014/jush.v25i2.3916.

Latief, M. Syahbuddin. Jalan Kemanusiaan, Panduan Untuk Memperkuat Hak Asasi Manusia. Yogyakarta: Lapera Pustaka Utama, 1999.

Llewellyn, A., and K. Hogan. "The Use and Abuse of Models of Disability." Disability \& Society 15, no. 1 (January 2000): 157-65. https://doi.org/10.1080/09687590025829.

Maftuhin, Arif. "Mengikat Makna Diskriminasi: Penyandang Cacat, Difabel, Dan Penyandang Disabilitas.” INKLUSI 3, no. 2 (August 8, 2016). https://doi.org/10.14421/ijds.030201.

Mubarok, Mohammad Yazid. “Hak-Hak Dan Kewajiban Kaum Disabilitas Sebelum Dan Setelah Islam Datang | Islamic Academika." Accessed July 2021. http://ejurnal.staiattaqwa.ac.id/index.php/ojs/article/view/84.

Niewyk, Donald L., and Francis R. Nicosia. The Columbia Guide to the Holocaust. Columbia University Press, 2003. 
Nursyamsi, Fajri. Kerangka Hukum Disabilitas Di Indonesia: Menuju Indonesia Ramah Disabilitas. Cetakan pertama. Jakarta: Pusat Studi Hukum dan Kebijakan, 2015.

Putusan Mahkamah Konstitusi Nomor 10-17-23/PUU-VII/2009 (n.d.).

Shihab, Quraish. Tafsir Al-Mishbah, Pesan, Kesan Dan Keserasian alQur'an. Jilid 8. Ciputat: Lentera Hati, 2009.

Undang-Undang Nomor 39 Tahun 1999 tentang Hak Asasi Manusia (n.d.).

Wolfensberger, Wolf. “A Brief Overview of Social Role Valorization.” Ment Retard 38, no. 2 (2000). https://doi.org/10.1352/00476765(2000)038<0105:ABOOSR >2.0.CO;2.

Writer. "Oxford.Dictionary. Diakses Tanggal 25 Januari 2021.<https://Www.Oxfordlearnersdictionaries.Com/>," n.d.

Zuhalili, Wahbah az-. Tafsir Al-Munir. Damaskus: Dar al-Fikr alMuashir, 1418. 